\title{
Layered Double Hydroxides as a Drug Delivery Vehicle for S-Allyl-Mercapto-Cysteine (SAMC)
}

\author{
Ivan Vito Ferrari ${ }^{1}$, Riccardo Narducci ${ }^{1, *}{ }^{\oplus}$, Giuseppe Prestopino ${ }^{1}\left(\right.$, Ferdinando Costantino ${ }^{2}{ }^{\circledR}$, \\ Alessio Mattoccia ${ }^{1}$, Lina Di Giamberardino ${ }^{1}$, Morena Nocchetti ${ }^{3}{ }^{(0)}$, Maria Luisa Di Vona ${ }^{1}$, Annalisa Paolone ${ }^{4}(\mathbb{D}$, \\ Marzia Bini ${ }^{3}$, Riccardo Pezzilli ${ }^{1}$, Ilaria Borromeo ${ }^{5}\left(\mathbb{D}\right.$, Simone Beninati ${ }^{6}\left(\mathbb{D}\right.$ and Pier Gianni Medaglia ${ }^{1, *}$
}

1 Department of Industrial Engineering, University of Rome "Tor Vergata", Via del Politecnico 1, 00133 Rome, Italy; ivanvitoferrari@gmail.com (I.V.F.); giuseppe.prestopino@uniroma2.it (G.P.); alessiomattoccia1@gmail.com (A.M.); biolina@yahoo.it (L.D.G.); divona@uniroma2.it (M.L.D.V.); riccardo.pezzilli@students.uniroma2.eu (R.P.)

2 Department of Chemistry, Biology and Biotechnologies, University of Perugia, Via Elce di Sotto 8, 06123 Perugia, Italy; ferdinando.costantino@unipg.it

3 Department of Pharmaceutical Sciences, University of Perugia, Via del Liceo 1, 06123 Perugia, Italy; morena.nocchetti@unipg.it (M.N.); marziabini91@gmail.com (M.B.)

4 Consiglio Nazionale delle Ricerche, Istituto dei Sistemi Complessi, U.O.S. La Sapienza, Piazzale A. Moro 5, 00185 Roma, Italy; annalisa.paolone@roma1.infn.it

5 Department of Physics, University of Rome "Tor Vergata”, Via della Ricerca Scientifica, 00133 Rome, Italy; ilaria18scv@hotmail.it

check for updates

Citation: Ferrari, I.V.; Narducci, R.; Prestopino, G.; Costantino, F.;

Mattoccia, A.; Di Giamberardino, L.; Nocchetti, M.; Di Vona, M.L.;

Paolone, A.; Bini, M.; et al. Layered Double Hydroxides as a Drug Delivery Vehicle for S-Allyl-Mercapto-Cysteine (SAMC) Processes 2021, 9, 1819. https:// doi.org/10.3390/pr9101819

Academic Editor: Yi Lu

Received: 23 September 2021

Accepted: 8 October 2021

Published: 14 October 2021

Publisher's Note: MDPI stays neutral with regard to jurisdictional claims in published maps and institutional affiliations.

Copyright: (c) 2021 by the authors. Licensee MDPI, Basel, Switzerland. This article is an open access article distributed under the terms and conditions of the Creative Commons Attribution (CC BY) license (https:// creativecommons.org/licenses/by/ $4.0 /)$.
6 Department of Biology, University of Rome "Tor Vergata", Via della Ricerca Scientifica, 00133 Rome, Italy; Beninati@bio.uniroma2.it

* Correspondence: riccardo.narducci@uniroma2.it (R.N.); medaglia@uniroma2.it (P.G.M.)

Abstract: The intercalations of anionic molecules and drugs in layered double hydroxides (LDHs) have been intensively investigated in recent years. Due to their properties, such as versatility in chemical composition, good biocompatibility, high density and protection of loaded drugs, LDHs seem very promising nanosized systems for drug delivery. In this work, we report the intercalation of S-allyl-mercapto-cysteine (SAMC), which is a component of garlic that is wellknown for its anti-tumor properties, inside ZnAl-LDH (hereafter LDH) nanostructured crystals. In order to investigate the efficacy of the intercalation and drug delivery of SAMC, the intercalated compounds were characterized using X-ray powder diffraction (XRD), Fourier-transform infrared spectroscopy (FT-IR) and scanning electron microscopy (SEM). The increase in the interlayer distance of LDH from $8.9 \AA$, typical of the nitrate phase, to $13.9 \AA$ indicated the intercalation of SAMC, which was also confirmed using FT-IR spectra. Indeed, compared to that of the pristine LDH precursor, the spectrum of LDH-SAMC was richly structured in the fingerprint region below $1300 \mathrm{~cm}^{-1}$, whose peaks corresponded to those of the functional groups in the SAMC molecular anion. The LDH-SAMC empirical formula, obtained from UV-Vis spectrophotometry and thermogravimetric analysis, was $\left[\mathrm{Zn}_{0.67} \mathrm{Al}_{0.33}(\mathrm{OH})_{2}\right] \mathrm{SAMC}_{0.15}\left(\mathrm{NO}_{3}\right)_{0.18} \cdot 0.6 \mathrm{H}_{2} \mathrm{O}$. The morphology of the sample was investigated using SEM: LDH-SAMC exhibited a more irregular size and shape of the flake-like crystals in comparison with the pristine LDH, with a reduction in the average crystallite size from $3 \mu \mathrm{m}$ to about $2 \mu \mathrm{m}$. In vitro drug release studies were performed in a phosphate buffer solution at $\mathrm{pH} 7.2$ and $37^{\circ} \mathrm{C}$ and were analyzed using UV-Vis spectrophotometry. The SAMC release from LDH-SAMC was initially characterized by a burst effect in the first four hours, during which, $32 \%$ of the SAMC is released. Subsequently, the release percentage increased at a slower rate until $42 \%$ after $48 \mathrm{~h}$; then it stabilized at $43 \%$ and remained constant for the remaining period of the investigation. The LDH-SAMC complex that was developed in this study showed the improved efficacy of the action of SAMC in reducing the invasive capacity of a human hepatoma cell line.

Keywords: ZnAl-LDH; intercalation compounds; S-allyl-mercapto-cysteine (SAMC); drug delivery; cancer; hepatoma; antitumor garlic derivative molecules 


\section{Introduction}

Chemotherapy with cytotoxic drugs is widely used for the treatment of cancer patients. However, the use of these drugs has shown the development of resistance of cancer cells to treatment with these anticancer agents. The complex biochemical mechanisms underlying the tumor cell transformation represent a major obstacle to the development of an ideal therapy for cancer, which is characterized by high efficacy with low side effects [1] Nanotechnology has changed the cancer treatment scenario. In recent decades, several inorganic materials, such as calcium phosphate, gold, carbon materials, silicon oxide, iron oxide and layered double hydroxides (LDHs), have been studied for targeted drug administration [2-10]. Drug delivery via LDHs showed great in vitro and in vivo potential for the administration of bioactive molecules to cells. Recent observations showed that LDH is more biocompatible than other commonly used nanoparticles. Several pharmacologically active molecules were associated with the surface or intercalated in LDH through co-precipitation, anionic exchange reactions or other methods $[11,12]$. Furthermore, these nanodevices were used on target cells or organs in therapeutic gene approaches $[13,14]$.

LDHs have been intensively studied for many decades due to their intriguing physicochemical properties. LDHs are also widely referred to as hydrotalcite-like compounds (HTlc) due to their structural similarities to hydrotalcite, which is a mineral with the formula $\mathrm{Mg}_{6} \mathrm{Al}_{2}(\mathrm{OH})_{16} \mathrm{CO}_{3} \cdot 4 \mathrm{H}_{2} \mathrm{O}$. They belong to the group of anionic clays, which are composed of divalent and trivalent metal cations that are coordinated to hydroxide anions in $\mathrm{M}(\mathrm{II})(\mathrm{OH})_{6}$ and $\mathrm{M}(\mathrm{III})(\mathrm{OH})_{6}$ edge-sharing octahedra, resulting in stacked sheets that are similar to those of brucite [15-18], as shown in Figure 1. The hydroxide layers in LDHs are positively charged due to the partial substitution of divalent metal cations by trivalent ones, and they are weakly bound to each other through the electrostatic interactions between the charged sheets and anions and by the hydrogen bonds between the hydroxides and the water molecules [19].

a)

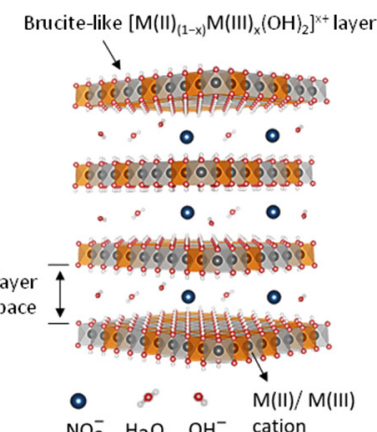

$\mathrm{NO}_{3}^{-} \mathrm{H}_{2} \mathrm{O} \quad \mathrm{OH}^{-}$cation

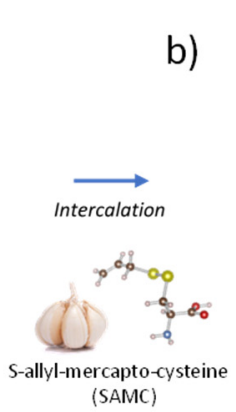

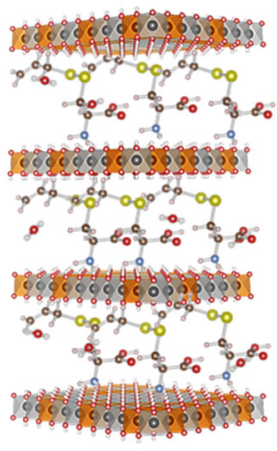

Figure 1. General structure of layered double hydroxide crystal containing layers of divalent $\mathrm{M}$ (II) and trivalent $\mathrm{M}$ (III) cations arranged between two layers of hydroxides. Water and $\mathrm{OH}^{-} \mathrm{or} \mathrm{NO}_{3}{ }^{-}$ anions are intercalated in the interlayer space (a), while more complex molecules or drugs can also be hosted (in this work, the garlic derivative SAMC molecule) after the anion exchange process (b).

Even though it is possible to realize a great variety of LDH compounds, there are some restrictions on the substitution fraction of the divalent metal cation, namely, the $\mathrm{M}(\mathrm{III}) /(\mathrm{M}(\mathrm{II})+\mathrm{M}(\mathrm{III}))$ molar fraction. Based on the evidence of experiments [20], this quantity has to be between 0.20 and 0.40 ; otherwise, it results in significant difficulty obtaining a pure hydrotalcite phase and avoiding the formation of other phases. LDHs are very versatile for different technological applications, in particular biological and chemical ones [21], primarily due to their layered structure, which allows for hosting even complex organic molecules, such as drugs and biomolecules, that are intercalated in the large interlayer space with wide flexibility regarding the composition and functionalization [22-28]. Moreover, there is currently an increasing interest in LDHs due to their properties as heterogeneous catalysts and supports for molecular catalysts [29-31] or photocatalysis [32], for fabrication of superhydrophobic surfaces [33,34], water treatment 
and remediation [35-37] and ion-exchanger membranes [38,39]. Interestingly, anion conductivity in LDHs can be modulated by incorporating different anions in the interlayer space, allowing for their use as sensors [40-44] or as fillers in different electrochemical applications, such as fuel cells, supercapacitors and water splitting [45-47].

Different types of LDH compounds and LDH-based nanocomposites and hybrids have been made available by several synthesis methods, including exfoliation or top-down methods, as well as several chemical or mechanical methods (see, for instance, $[48,49]$ ). It was demonstrated that owing to their advantages, such as their low cost, the versatility of their chemical composition, the easy tunability of physicochemical properties, a wide range of preparation variables, unique anion exchange and intercalation properties, chemical stability and colloidal behavior, LDHs can be effectively used as nanoscale vehicles in drug delivery $[11,50,51]$. In particular, LDHs possess good biocompatibility, high drug-loading density, high drug-transportation efficiency and low toxicity to target cells or organs, as well as offer excellent protection to loaded molecules from undesired enzymatic degradation $[49,52]$. Furthermore, the intercalation of organosulfur compounds L-cystine and L-cysteine in MgAl-LDHs by co-precipitation and ion exchange methods was demonstrated in a previous study [53].

In this work, we report on ZnAl-LDH (hereafter LDH) that was synthetized using a urea method for drug delivery of S-allyl-mercapto-cysteine (SAMC), which is a component of garlic, as well as other garlic-derived and organosulfur compounds, such as L-cysteine, DADS, SAC and L-cystine, which have been studied over the years. Their molecular structures are shown in Figure 2 [54-56]. SAMC is well-known for its antitumor properties, as demonstrated by many recently reported both in vitro and in vivo studies [57-62]. Experimental carcinogenesis studies indicate that the components of garlic (e.g., allyl sulfides) inhibit both the initiation and promotion stages of tumorigenesis for various types of cancer, including colorectal, lung and skin cancers. The garlic derivative SAMC can inhibit the growth of cancer cells by directly binding to sulfhydryl residues in tubulin and thereby disrupt microtubule structures in the cytoplasm of interphase cells and the spindle apparatus of mitotic cells [59]. Furthermore, SAMC is able to stop the cell cycle, preventing progression from phase $\mathrm{G} 2$ to phase $M$, which inhibits the protein kinases involved in signal transduction, blocks the opening of calcium channels and, finally, modifies the reactivity of steroid hormones with cancer cells [60].<smiles>N[C@@H](CS)C(=O)O</smiles>

L-cysteine<smiles>C=CCSSCC=C</smiles>

Diallyl disulfide (DADS)<smiles>C=CCSC[C@H](N)C(=O)O</smiles>

S-allylcysteine (SAC)<smiles>N[C@@H](CSSC[C@H](N)C(=O)O)C(=O)O</smiles>

L-cystine<smiles>C=CCSSC[C@H](N)C(=O)O</smiles>

S-allylmercapto-L-cysteine (SAMC)

Figure 2. Molecular structures of garlic-derived and other organosulfur compounds: L-cysteine, DADS, SAC, L-cystine and SAMC.

\section{Materials and Methods}

\subsection{Materials}

All purchased reagents were used without further purification. SAMC was kindly granted by the Wakunaga Pharmaceutical Company, Ltd. (Tokyo, Japan). SAMC was assayed in the culture media by means of a fluorimetric kit (ab211099-ABCAM Discov- 
ery Drive, Cambridge Biomedical Campus, Cambridge, UK). LDH was synthesized by using $\mathrm{Zn}\left(\mathrm{NO}_{3}\right)_{2} \cdot 6 \mathrm{H}_{2} \mathrm{O}$ and $\mathrm{Al}\left(\mathrm{NO}_{3}\right)_{3} \cdot 9 \mathrm{H}_{2} \mathrm{O}$, which were purchased from Fluka-Honeywell (Seelze, Germany) and Alfa Aesar (Thermo Fisher Scientific Chemicals, Inc., Ward Hill, MA, USA), respectively. The urea compound was purchased from Sigma Aldrich (Merk Life Science, Milan, Italy). In vitro release studies were carried out in Dulbecco's Phosphate Buffered Saline 10X D-PBS (Euroclone S.p.A.). Deionized water was obtained via a reverse osmosis process that was carried out using the Milli Q system (Millipore, Roma, Italia). All the other reagents and solvents were characterized by the highest value of purity.

\subsection{Synthesis of $L D H$}

Micrometric LDHs with the formula $\left[\mathrm{Zn}_{0.67} \mathrm{Al}_{0.33}(\mathrm{OH})_{2}\right]\left(\mathrm{NO}_{3}\right)_{0.33} \cdot 0.6 \mathrm{H}_{2} \mathrm{O}\left(\mathrm{LDH}-\mathrm{NO}_{3}\right)$ were synthesized as reported in the literature [63]: $1.0 \mathrm{M}$ solution of $\mathrm{Zn}(\mathrm{II})$ and $\mathrm{Al}(\mathrm{III})$, with a molar fraction $\mathrm{Al}(\mathrm{III}) /(\mathrm{Al}(\mathrm{III})+\mathrm{Zn}(\mathrm{II}))=0.33$, was prepared by dissolving $\mathrm{Zn}\left(\mathrm{NO}_{3}\right)_{2} \cdot 6 \mathrm{H}_{2} \mathrm{O}$ $(41.65 \mathrm{~g}, 0.14 \mathrm{~mol})$ and $\mathrm{Al}\left(\mathrm{NO}_{3}\right)_{3} \cdot 9 \mathrm{H}_{2} \mathrm{O}(26.26 \mathrm{~g}, 0.07 \mathrm{~mol})$ in $200 \mathrm{~mL}$ of decarbonated water. Finally, $0.42 \mathrm{~mol}$ of solid urea was added to this solution in order to have a urea/Al molar ratio value of 6 . The obtained solution was heated under stirring and $\mathrm{N}_{2}$ flux for $24 \mathrm{~h}$ at $100{ }^{\circ} \mathrm{C}$. The resulting material was recovered via centrifugation, washed several times with degassed water and dried at $65{ }^{\circ} \mathrm{C}$ in an oven. The mass of the obtained material was $22.2 \mathrm{~g}$, with a percentage yield close to $90 \%$.

\subsection{Intercalation of S-Allyl-Mercapto-Cysteine into LDH (LDH-SAMC)}

The SAMC $(0.405 \mathrm{~g}, 0.0021 \mathrm{~mol}, \mathrm{MW}=193.3, \mathrm{pKa}=9.04)$ was dissolved in $20 \mathrm{~mL}$ of degassed water, and $1 \mathrm{M} \mathrm{NaOH}$ solution $(2.1 \mathrm{~mL})$ was added in order to obtain the corresponding anionic form of SAMC at $\mathrm{pH}=10$. Finally, $\mathrm{LDH}^{-N_{3}}(0.500 \mathrm{~g}, 0.0042 \mathrm{~mol}$, $\mathrm{MW}=117.99$ ) was dispersed in the previously closed system solution and the SAMC/Al molar ratio was 1.5. This mixture was kept under magnetic stirring at room temperature (RT) for $24 \mathrm{~h}$.

The resulting solid (hereafter LDH-SAMC) was filtered under vacuum and washed twice with degassed water and then dried in an oven at $65^{\circ} \mathrm{C}$ for $24 \mathrm{~h}$. The obtained material was stored under $\mathrm{P}_{2} \mathrm{O}_{5}$ at RT. The LDH-SAMC intercalation compound was characterized using XRD, SEM and FT-IR. The amount of the intercalated drug was determined using UV-Vis spectrophotometry and thermogravimetric analysis.

\subsection{Release Study of SAMC from LDH-SAMC}

The SAMC release was performed in a phosphate buffer solution (PBS) at pH 7.2. The release studies in PBS were carried out by dispersing $127 \mathrm{mg}$ of LDH-SAMC in $107 \mathrm{~mL}$ of medium in a closed vessel under stirring. The temperature was kept constant at $37.0 \pm 0.5^{\circ} \mathrm{C}$ using a thermostatically controlled circulation water bath.

Withdrawals of $2 \mathrm{~mL}$ were done at fixed times and the same volume of fresh medium was added after each sampling. Samples were centrifuged (Sigma 3-30KS) to obtain clear supernatants, diluted when necessary, then were analyzed using UV spectrophotometry (Agilent 8453) at $\lambda_{\max }=202 \mathrm{~nm}$ according to the calibration curve previously determined $\left(y=-1.5398 \times 10^{-5}+1.7899 \times 10^{-4} x, \mathrm{r}=0.9885\right.$, standards from $5.2 \times 10^{-5} \mathrm{M}$ to $\left.1.6 \times 10^{-4} \mathrm{M}\right)$. Any solid recovered after centrifugation was re-immersed in the initial dispersion. Drug release was monitored starting from shorter intervals (e.g., $15 \mathrm{~min}$ ) to longer ones over about 13 days and the SAMC concentration was reported as an average of three determinations. The percentage released at each time was expressed as a percentage of the total amount of SAMC.

At the end of the release experiment, the solid was recovered via centrifugation, dried and analyzed using X-ray powder diffraction.

\subsection{Characterization}

X-ray powder diffraction (XRD) patterns were collected using a PanalyticalX'Pert PRO diffractometer and a PW3050/60 goniometer equipped with an $X^{\prime}$ Celerator detector, 
a $\mathrm{CuK} \alpha$ radiation source, a $2 \theta$ step size of $0.033^{\circ}$ and a step scan of $50 \mathrm{~s}$. The LFF ceramic tube was operated at $40 \mathrm{kV}$ and $40 \mathrm{~mA}$. To minimize the preferred orientation, the powder samples were carefully side-loaded onto a glass sample holder and rectangle-shaped film stripes were loaded onto an aluminum sample holder.

Thermogravimetric analysis (TGA) was carried out using a thermoanalyzer (TG-DTA Netzsch STA 490) at a heating rate of $10^{\circ} \mathrm{C} / \mathrm{min}$ with a $30 \mathrm{~mL} / \mathrm{min}$ airflow.

The morphologies of the LDH and LDH-SAMC samples were investigated by means of scanning electron microscopy (SEM) secondary electron images that were taken in a field emission SEM (FESEM, model LEO SUPRA 1250, Oberkochen, Germany). In order to prevent possible charging effects during imaging, all samples were covered with a thin gold layer (approximately $5 \mathrm{~nm}$ ). Images were collected using a $5 \mathrm{kV}$ accelerated electron beam.

FT-IR (Fourier-transform infrared) spectra were measured by means of an Agilent 660 spectrometer. Each sample was dissolved in $\mathrm{KBr}$ powder in a weight ratio of 1:100 and compacted in a self-standing specimen. The pellets were measured in transmission mode between 400 and $6000 \mathrm{~cm}^{-1}$ using a ceramic source, a KBr beam splitter and a DTGS detector.

The amount of SAMC in the sample was determined using UV-Vis spectrophotometry (Agilent 8453) at $\lambda_{\max }=202 \mathrm{~nm}$.

\subsection{Cell Cultures}

Human hepatocarcinoma (HepG2) cells were purchased from the European Collection of Cell Cultures (Promochem, Beirut, Lebanon); grown in glutamine-containing RPMI 1640 medium (Sigma, St. Louis, MO, USA) that was supplemented with 1\% sodium pyruvate, $1 \%$ non-essential amino acids and 10\% fetal calf serum (FCS); and incubated at $37^{\circ} \mathrm{C}$ in an atmosphere of $5 \% \mathrm{CO}_{2}$ in the air. Cells were routinely trypsinized and plated at a density of $4 \times 10^{4}$ cells $/ \mathrm{cm}^{2}$.

\subsection{Cellular Treatments}

LDH-SAMC suspensions were kept at room temperature just before use and added to the cell medium at concentrations of $0.1,0.5$ and $1 \%(v / v)$. These solutions correspond to a final concentration of SAMC on the cell medium ranging from 5 to $50 \mu \mathrm{M}$. In parallel, as a control, the data were compared with cultures in the presence of SAMC alone at the same concentrations. The optimal concentration of SAMC was chosen and showed a sufficiently cytostatic and less toxic effect on the cells (data not shown).

\subsection{Analysis of Cell Viability (Cytotoxicity)}

Cell viability was assessed by staining the cells with Trypan Blue 0.4\% (Sigma) according to the protocol described by W. Strober [64]. For cell viability analysis, cultures were treated with an LDH-SAMC suspension at concentrations of $0.1,0.5$ and $1 \%(v / v)$ or with a solution of SAMC at a final concentration ranging from 5 to $50 \mu \mathrm{M}$. After the treatment times, specifically 24 and $48 \mathrm{~h}$, the culture medium was recovered and the cells were washed twice with $2 \mathrm{~mL}$ of PBS. They were then detached from the flask by the addition of $1 \mathrm{~mL}$ of trypsin/EDTA (ethylenediaminetetraacetic acid) by Biowest and recovered for further analysis. To ensure that all cells were retrieved from the flask, an additional wash in PBS was performed. Subsequently, 50-100 $\mu \mathrm{L}$ of cell suspension was added to 50-100 $\mu \mathrm{L}$ of Trypan Blue; after 5 min of incubation at room temperature, viable cells were loaded and counted using a Burker chamber under a phase-contrast light microscope.

\subsection{Cell Migration Assay Using the Scratch Test}

The ability of HepG2 cells, untreated or treated with either LDH-SAMC or SAMC alone, to reform a monolayer at $100 \%$ confluence after mechanical shear was evaluated using the "scratch test" method [65]. Scratching involves a longitudinal surface incision at the plate diameter, which generates a directional migratory response. HepG2 cells were expanded in $75 \mathrm{~cm}^{2}$ flasks until approximately $90 \%$ confluence was reached. After being 
removed from the medium, cells were washed 2 times with $2 \mathrm{~mL}$ of PBS, then detached via the addition of $1 \mathrm{~mL}$ of trypsin/EDTA, incubated for $5 \mathrm{~min}$ at $37^{\circ} \mathrm{C}$ and $5 \% \mathrm{CO}_{2}$, resuspended in $9 \mathrm{~mL}$ of complete medium and finally harvested in a $50 \mathrm{~mL}$ Falcon tube. Subsequently, they were seeded in a 6-well plate (3-3.5 mL of cell suspension per well) and incubated with $0.1,0.5$ and $1 \%(v / v)$ LDH-SAMC suspensions or SAMC at a final concentration of 5,25 or $50 \mu \mathrm{M}$ for $24 \mathrm{~h}$ at $37{ }^{\circ} \mathrm{C}$ and $5 \% \mathrm{CO}_{2}$ to allow the formation of a complete monolayer. Once the confluence was reached, the medium was removed and the incision was made with a spatula that was previously treated with ethyl alcohol. After removing the debris produced as a result of cutting, the monolayer of HepG2 cells was washed 3 times with PBS and maintained in the presence of a culture medium. The incision areas were visualized under a microscope after $48 \mathrm{~h}$ of incubation. Cell migration and the effect of treatments on sulcus closure were assessed as the number of cells that migrated within the sulcus itself over $48 \mathrm{~h}$ via image acquisition and analysis using "Image J" software (ImageJ bundled with 64-bit Java 1.8.0_172). Data were expressed as the percentage migration compared to the control placed at $100 \%$.

\section{Results and Discussion}

\subsection{Preparation and Characterization of LDH-SAMC}

Since nitrate anions are easier to exchange in comparison with carbonate or chloride anions, LDH in nitrate form was chosen as the starting material to intercalate SAMC anions. The intercalation of the SAMC in anionic form occurred via an ion-exchange reaction in agreement with the following reaction:

$$
\mathrm{LDH}_{-} \mathrm{NO}_{3}+\mathrm{SAMC}^{-} \rightarrow \mathrm{LDH}-\mathrm{SAMC}+\mathrm{NO}_{3}{ }^{-}
$$

The XRD patterns of $\mathrm{LDH}-\mathrm{NO}_{3}$ and $\mathrm{LDH}-\mathrm{SAMC}$ are shown in Figure $3 . \mathrm{LDH}-\mathrm{NO}_{3}$ was well crystallized and the peak at $8.9^{\circ}$ of $2 \theta$ was related to the presence of the pure nitrate form. After intercalation, the (003) reflection was shifted to lower $2 \theta$ values corresponding to $13.9 \AA$, which confirmed the successful intercalation of $\mathrm{SAMC}^{-}$anions. The absence of the peaks belonging to the pristine phase suggested that the nitrate anions that were not exchanged by SAMC (see the chemical composition reported below) were solubilized in the SAMC phase with the formation of a solid solution. A loss of crystallinity upon intercalation, probably due to stacking disorder, was observed, as confirmed via a general broadening of the peaks.

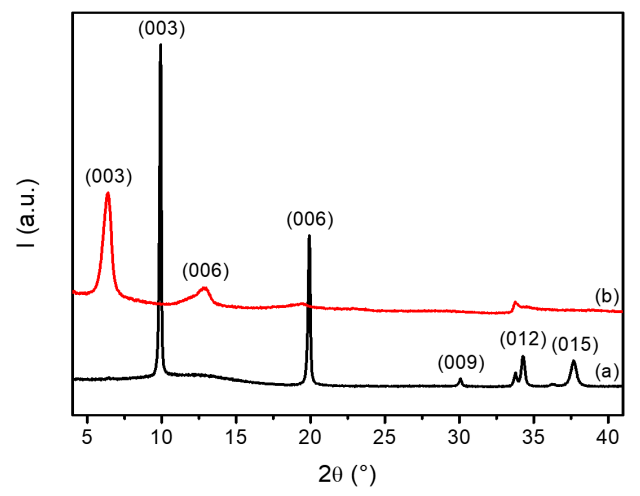

Figure 3. XRD patterns of $\mathrm{LDH}^{-\mathrm{NO}_{3}}$ (a) and LDH-SAMC (b).

The chemical composition of the intercalation compound was investigated by combining the thermal analysis (TGA) and UV measurements. Moreover, the TGA allowed for studying the thermal stability of LDH-SAMC. The TGA curves for $\mathrm{LDH}_{-} \mathrm{NO}_{3}$ and $\mathrm{LDH}-$ $\mathrm{SAMC}$ are shown in Figure 4. $\mathrm{LDH}-\mathrm{NO}_{3}$ displayed a first weight loss of $8.4 \%$ up to $170{ }^{\circ} \mathrm{C}$, which was due to the loss of intercalated water molecules. Then, a second weight loss up to $600{ }^{\circ} \mathrm{C}$ was observed, which was compatible with the loss of nitrate from the interlayer region and water coming from the layer dehydroxylation with the formation of $\mathrm{ZnO}$ and 
$\mathrm{ZnAl}_{2} \mathrm{O}_{4}$. The TGA of LDH-SAMC showed three weight losses: the first, from 70 to $170{ }^{\circ} \mathrm{C}$, was related to the hydration water; the second, until $600{ }^{\circ} \mathrm{C}$, was due to the loss of residual nitrates, layer dehydroxylation and decomposition of SAMC; the third could be ascribable to the decomposition of $\mathrm{ZnSO}_{4}$ that was formed upon the SAMC decomposition. Finally, it was possible to assign to LDH-SAMC the following formula:

$$
\left[\mathrm{Zn}_{0.67} \mathrm{Al}_{0.33}(\mathrm{OH})_{2}\right] \mathrm{SAMC}_{0.15}\left(\mathrm{NO}_{3}\right)_{0.18} \cdot 0.6 \mathrm{H}_{2} \mathrm{O}
$$

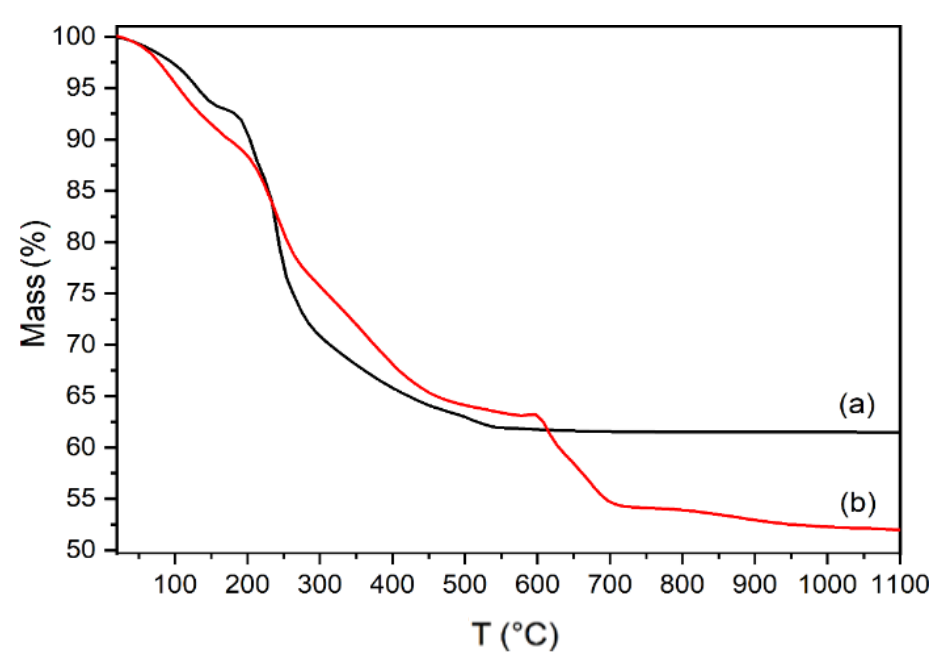

Figure 4. TGA curves for $\mathrm{LDH}_{-N O}$ (a) and LDH-SAMC (b). Operative conditions: heating rate of $10{ }^{\circ} \mathrm{C} / \mathrm{min}$ in a $30 \mathrm{~mL} / \mathrm{min}$ airflow.

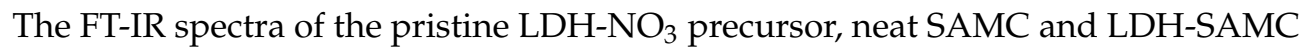
are displayed in Figure $5(\mathrm{a}, \mathrm{b}, \mathrm{c})$, respectively. The FT-IR spectrum of the LDH pristine precursor (Figure 5 (a)) showed the characteristic features that are widely reported for LDH$\mathrm{NO}_{3}$. Briefly, the $\mathrm{O}-\mathrm{H}$ stretching vibration in the brucite-like layers and the hydration water molecules produced a broad band in the $3000-3800 \mathrm{~cm}^{-1}$ range, centered at approximately $3480 \mathrm{~cm}^{-1}[66,67]$, whose broadening is typically attributed to hydrogen bonds formed between the hydroxides and the hydration water molecules [68]. The band observed near $1617 \mathrm{~cm}^{-1}$ was assigned to the bending vibration of the interlayer water molecules [69]. A strong absorption band at about $1384 \mathrm{~cm}^{-1}$ arose from the $v_{3}$ stretching vibrations of free interlayer nitrate anions with $D_{3 h}$ symmetry, as confirmed by the presence of bands at 1762 and $834 \mathrm{~cm}^{-1}$ [70]. The narrow peak at $1050 \mathrm{~cm}^{-1}$ could be assigned to the intercalated $\mathrm{NO}_{3}{ }^{-}$as well [71]. The bands in the low-frequency region were due to the lattice vibrations, i.e., to all of the metal-hydroxide stretching and bending modes $[69,72]$. In particular, the narrow band at about $427 \mathrm{~cm}^{-1}$ arose from metal-oxygen bond M-O-M vibrations in the brucite-like layer [66], and the broader band at approximately $608 \mathrm{~cm}^{-1}$ was attributed to the lattice vibration modes that are relevant to the $\mathrm{Zn}-\mathrm{OH}$ translation lattice modes [69].

The FT-IR spectrum of neat SAMC (Figure 5 (b)) was similar to those of L-cysteine [56,73], S-allylcysteine (SAC) [56], diallyl disulphide (DADS) [54] and L-cystine [55] due to the identical functional groups in their respective molecular structures (see Figure 1). The SAMC spectrum was also compared with the standard assignments of functional groups [74]. A shoulder at approximately $3429 \mathrm{~cm}^{-1}$ was consistent with the amine N-H stretch [55]. 


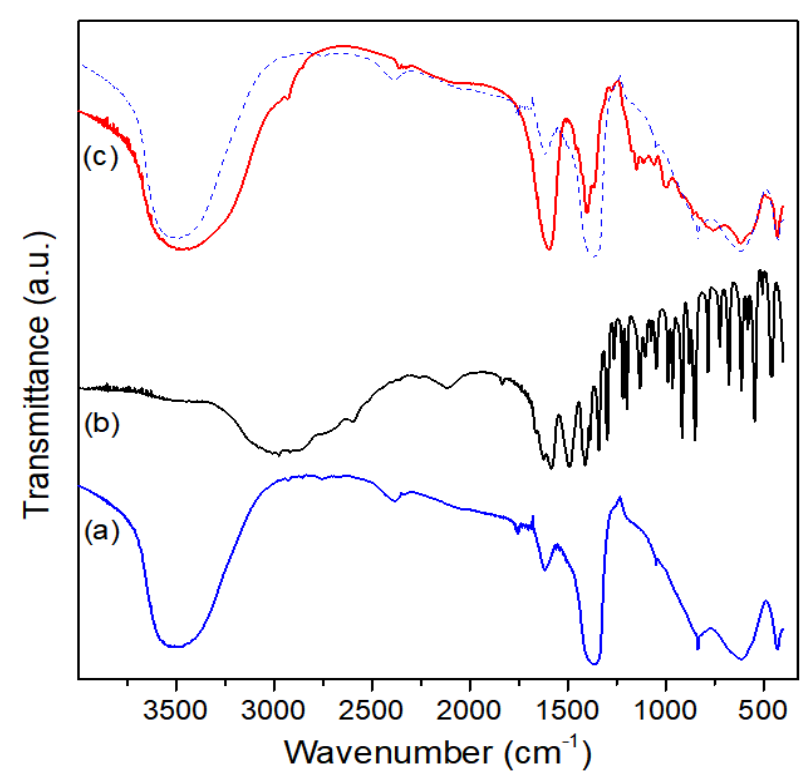

Figure 5. FT-IR spectra of the (a) pristine $\mathrm{LDH}^{-\mathrm{NO}_{3}}$ precursor, (b) neat SAMC crystal, and (c) LDH-SAMC. The dotted line corresponds to the pristine $\mathrm{LDH}^{-N_{3}}$ precursor for comparison purposes.

The presence of the amine group was also confirmed by the band at $1489 \mathrm{~cm}^{-1}$ due to the deformation of N-H [55]. A broad band around $3000 \mathrm{~cm}^{-1}$ was assigned to O-H stretching mode of the carboxylic group [75]. Weak sharp features in the wavenumber region $2850-3080 \mathrm{~cm}^{-1}$ were related to $\mathrm{C}-\mathrm{H}$ stretching vibrations. The bands at 988 and $916 \mathrm{~cm}^{-1}$ were due to alkene $\mathrm{RCH}=\mathrm{CH}_{2} \mathrm{CH}$ and $\mathrm{CH}_{2}$ out-of-plane deformation, respectively, the latter with an overtone at $1834 \mathrm{~cm}^{-1}$ [74]. As for the $\mathrm{NH}_{2} \mathrm{RCOOH}$ acid side of SAMC, in a non-ionized carboxylic $(\mathrm{COOH})$ group, the carbonyl $(\mathrm{C}=\mathrm{O})$ asymmetric stretching vibration occurred in the wavenumber region $1750-1700 \mathrm{~cm}^{-1}$ and it shifted to $1695-1540 \mathrm{~cm}^{-1}$ for the carboxylate ion $\left(\mathrm{COO}^{-}\right)$. The absorption bands at 1585 and $1411 \mathrm{~cm}^{-1}$ could therefore be assigned to asymmetric and symmetric stretching of $\mathrm{COO}^{-}$, whose rocking mode produces absorption at $611 \mathrm{~cm}^{-1}$ [55]. The peak at $1490 \mathrm{~cm}^{-1}$ could be attributed to symmetric $-\mathrm{NH}_{3}{ }^{+}$deformation. Interestingly, similarly to L-cysteine [55], these assignments made it reasonable to also suppose a zwitterionic nature for SAMC in the solid state. Peaks due to C-C stretching vibrations occurred in the $1194-1190 \mathrm{~cm}^{-1}$ range. The lower frequency peaks at 458 and $580 \mathrm{~cm}^{-1}$ are assigned to S-S stretching [55] and C-S-S-C bend [54], while those at 676 and $722 \mathrm{~cm}^{-1}$ were due to C-S stretching $[55,74]$.

The FT-IR spectrum of LDH-SAMC is shown in Figure 5 (c). Some characteristic peaks of pristine LDH were found, like the broad band at approximately $3400 \mathrm{~cm}^{-1}$ due to $\mathrm{O}-\mathrm{H}$ stretching vibrations, as well as the $\mathrm{M}-\mathrm{O}-\mathrm{M}$ skeletal stretching $\left(427 \mathrm{~cm}^{-1}\right)$ and the $\mathrm{M}$ $\mathrm{OH}$ bending vibrations $\left(770-550 \mathrm{~cm}^{-1}\right)$ in the brucite-like sheets. Compared to that of the pristine LDH precursor, the FT-IR spectrum of the LDH-SAMC exhibited a richly structured spectrum in the fingerprint region below $1300 \mathrm{~cm}^{-1}$, whose peaks corresponded to those of the functional groups in the SAMC molecule. In particular, the contributions from C-C stretching vibrations around $1100 \mathrm{~cm}^{-1}, \mathrm{C}-\mathrm{H}$ deformation at $993 \mathrm{~cm}^{-1}$ and C-S stretching vibration in the region $700-600 \mathrm{~cm}^{-1}$ could be clearly observed. Characteristic peaks due to C-H stretching vibrations in the range of $2800-2950 \mathrm{~cm}^{-1}$ also appeared in the LDH-SAMC spectrum. After the SAMC intercalation in the LDH interlayer galleries, the $1500-1350 \mathrm{~cm}^{-1}$ region in the FT-IR spectrum (see Figure 5 (c)) was dominated by absorptions due to $\mathrm{COO}^{-}$ asymmetric $\left(1587 \mathrm{~cm}^{-1}\right)$ and symmetric $\left(1399 \mathrm{~cm}^{-1}\right)$ stretching, which overlapped those that were assigned to the bending vibration of the interlayer water and stretching of the residual $\mathrm{NO}_{3}{ }^{-}$groups, respectively. The presence of $\mathrm{NO}_{3}{ }^{-}$was in agreement with the chemical composition that was obtained using UV and TGA. Interestingly, the intense absorption at $1490 \mathrm{~cm}^{-1}$ that was found in the SAMC spectrum (Figure 5 (b)) and tentatively 
assigned to $\mathrm{NH}_{3}{ }^{+}$group was not present in the FT-IR spectrum of LDH-SAMC that was found according to the intercalation procedure performed at $\mathrm{pH} 10$ in which SAMC was mainly present in anionic form. These results also confirm that after the ion exchange, SAMC into LDH preserved its functionality and structure. Such capability of LDHs was already reported for intercalation of other drug molecules [76-79], including L-cystine and L-cysteine [53].

The morphological features of the LDH-SAMC were investigated using FE-SEM and compared with the pristine components, i.e., SAMC and $\mathrm{LDH}^{-\mathrm{NO}_{3}}$ (Figure 6). The SAMC crystals exhibited a flaky morphology with a smooth surface and large micrometer-sized aggregates consisting of an almost flat stacking of elongated hexagonal flakes (Figure 6a). The FE-SEM micrograph of pristine $\mathrm{LDH}-\mathrm{NO}_{3}$ revealed the typical aggregation of clusters of small randomly oriented hexagonal-like platelets [80,81]. The diameter of LDH$\mathrm{NO}_{3}$ crystallites, as estimated from the FE-SEM image of Figure $6 \mathrm{~b}$, was about $3 \mu \mathrm{m}$. Furthermore, as shown in Figure 6c, LDH-SAMC exhibited roughly the same morphological features of the pristine LDH precursor with thin hexagonal-like platelets. However, more irregular sizes and shapes of the flake-like crystals could be clearly observed, as well as an overall finer structure with a reduction in the average crystallite size to about $2 \mu \mathrm{m}$. It is worth pointing out that the roughly identical morphology of $\mathrm{LDH}-\mathrm{NO}_{3}$ and LDH-SAMC, which was completely different from that of SAMC (see Figure 6a), clearly indicated that both the metal hydroxide sheets and the plate-like geometry of the LDH precursors were preserved during the anion exchange modification, as confirmed by the XRD results. Moreover, the broadening of the XRD reflections in the LDH-SAMC spectrum that is reported in Figure 3 well supported the loss of crystallinity due to the crystallite size reduction.
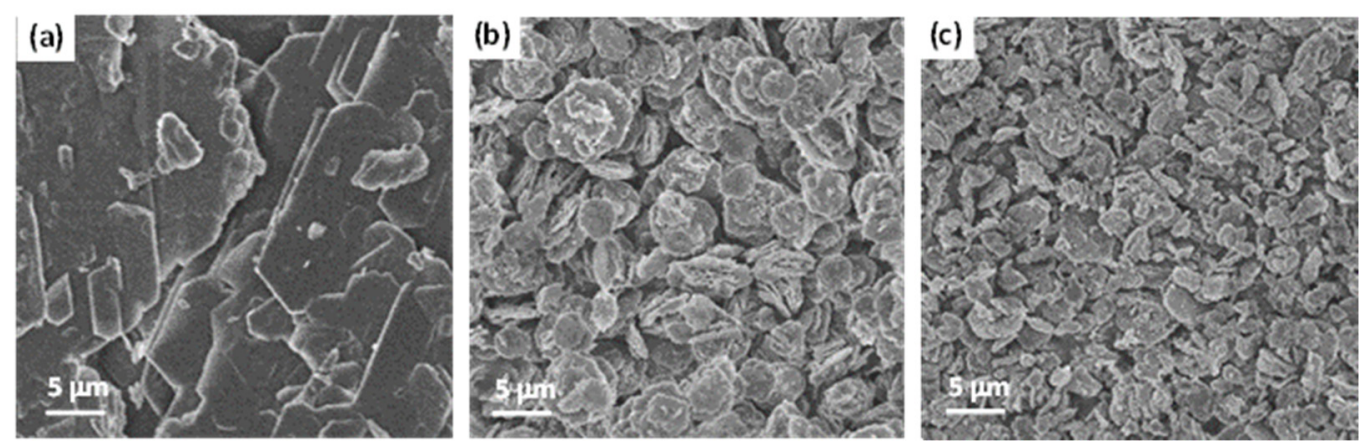

Figure 6. FE-SEM images of (a) SAMC alone, (b) pristine $\mathrm{LDH}^{-N_{3}}$ and (c) LDH-SAMC.

\subsection{SAMC Release Studies from LDH-SAMC}

An in vitro drug release study, reported in Figure 7, was performed in a phosphate buffer solution at $\mathrm{pH} 7.2$ and $37^{\circ} \mathrm{C}$. The SAMC release from LDH-SAMC was initially characterized by a clear burst effect in the first four hours, during which, $32 \%$ of the SAMC was released. This fact may be explained by the liberation of SAMC anions that were immobilized on the surface of the nanocrystals and those intercalated the edges of the interlayer regions. Subsequently, the percentage release increased at a slower rate, reaching $42 \%$ after $48 \mathrm{~h}$. Once the $48 \mathrm{~h}$ had elapsed, the percentage stabilized at $43 \%$ and remained constant for the entire period of the investigation. 


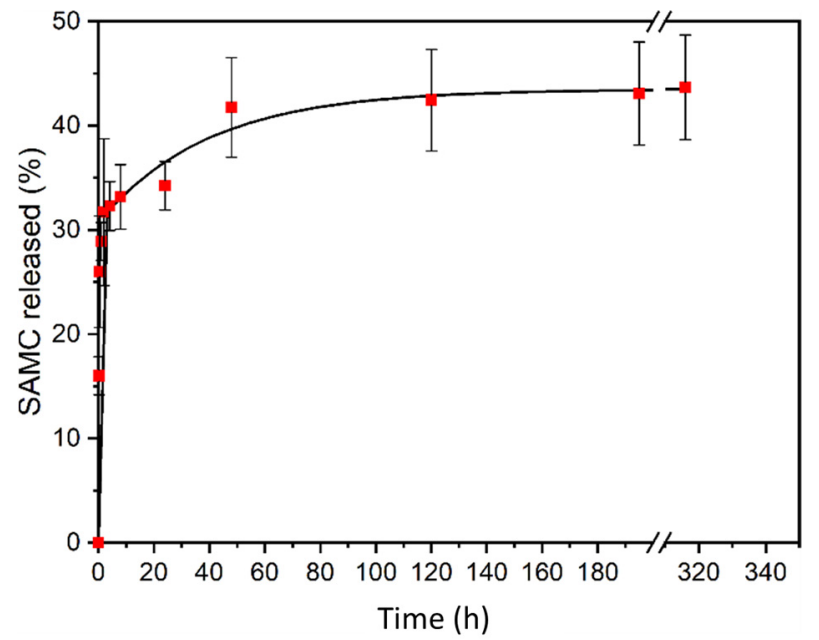

Figure 7. Release curve of SAMC from the LDH-SAMC. Operative conditions: phosphate buffer medium at $\mathrm{pH} 7.2$.

The solid recovered from the release experiments was characterized using XRD. Since the total release was lower than $40 \%$, the pattern of the recovered LDH-SAMC, shown in Figure 8, displayed a reflection corresponding to $14.7 \AA$, which very likely belonged to the SAMC phase. This interlayer distance suggested that the anions of the phosphate buffer solution, both as hydrogenphosphates and dihydrogenphosphates, were mainly present on the LDH surface and intercalated in the SAMC phase.

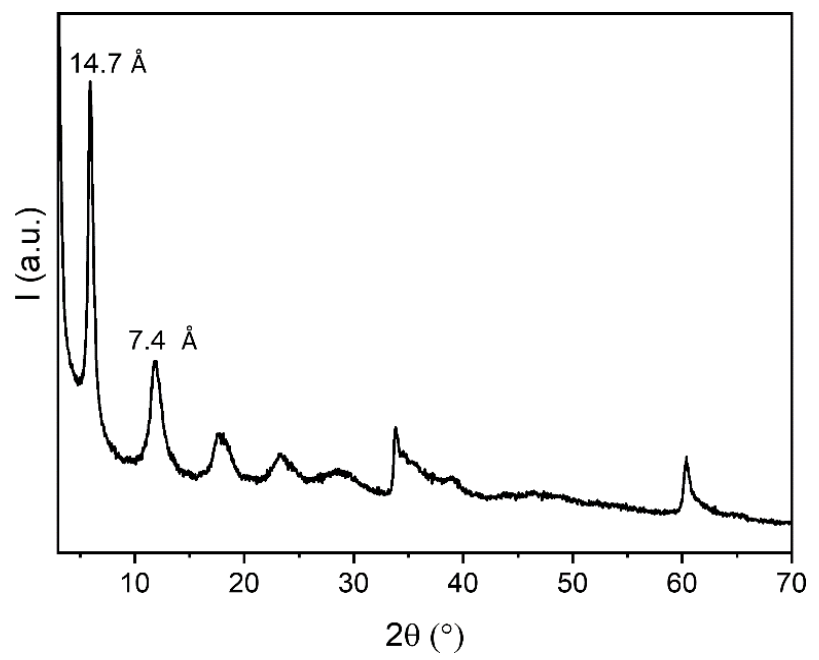

Figure 8. XRD pattern of the LDH-SAMC that was recovered after the release studies.

\subsection{Cytotoxicity of the LDH-SAMC and SAMC Treatments}

The cytotoxicity of the treatments was assessed using the Trypan Blue exclusion test (see the Materials and Methods section). The HepG2 cells were treated for $48 \mathrm{~h}$ in the presence of different concentrations of the SAMC loaded in the LDH (Figure 9a) or SAMC alone (Figure 9b). As can be seen in Figure 9a, the LDH-SAMC suspension showed similar levels of cytotoxicity to those subjected to the SAMC treatment alone, where the percentage of cytotoxicity after $48 \mathrm{~h}$ of incubation ranged from 15.4 to $18.5 \%$. In contrast, the HepG2 cellular samples, treated with LDH suspension for $48 \mathrm{~h}$, showed negligible cytotoxicity (Figure 9a). The percentages of cytotoxicity, shown in the figures, represent the mean \pm the standard deviation (SD) of two independent experiments, with each experiment carried out in triplicate; therefore, the total number of replicas was six $(n=6)$. In conclusion, as expected, the HepG2 cells showed low cytotoxicity after $48 \mathrm{~h}$ of incubation, both in the presence of the LDH-SAMC components and in the SAMC treatments. 

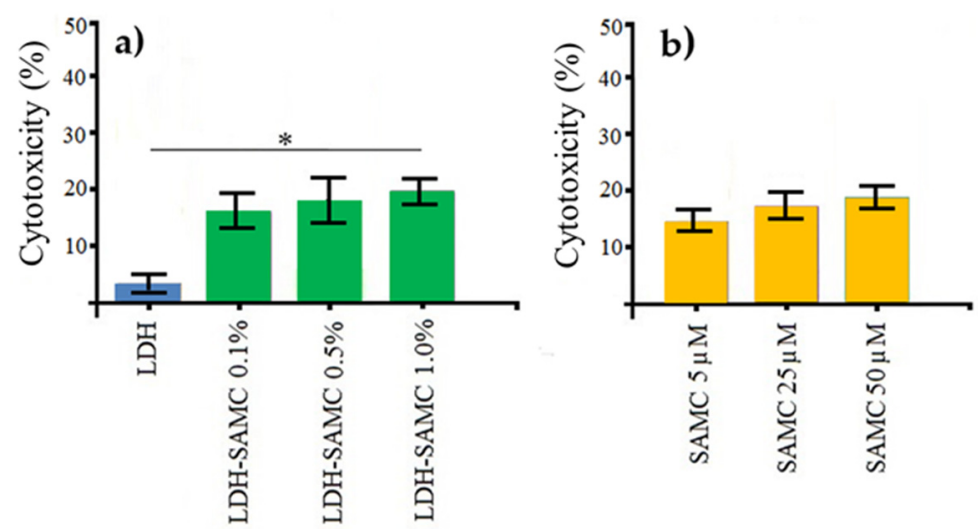

Figure 9. Percentage of cytotoxicity of the HepG2 cells after $48 \mathrm{~h}$ of treatment with the suspension of pristine LDH and LDH-SAMC (a) and SAMC alone (b) at several concentrations. Values represent the mean \pm SD of 2 independent experiments $(n=6)$ (Student's $t$-test; ${ }^{*} p<0.01$ compared to the control).

\subsection{Treatment of HepG2 Cells with the LDH-SAMC Complex Enhanced the Inhibition of Tumor Migration}

To characterize the efficacy of SAMC delivery via the intercalation in LDH, tumor cell migration was assessed by scratch test (Figure 10) and compared by culturing HepG2 cells in the presence of different concentrations of the drug loaded inside the LDH (Figure 11a) or alone (Figure 11b). The graph in Figure 11a shows a clear improvement in the inhibition of the migratory capacity of HepG2 cells when SAMC was delivered by LDH. In fact, after $48 \mathrm{~h}$ of incubation in the presence of LDH-SAMC at 1.0\%, the reduction in the migration reached $90 \%$ (Figure 11a) compared to the control set at 100. SAMC alone, at $50 \mu \mathrm{M}$ concentrations, could reduce the migration by $70 \%$ (Figure $11 \mathrm{~b}$ ).

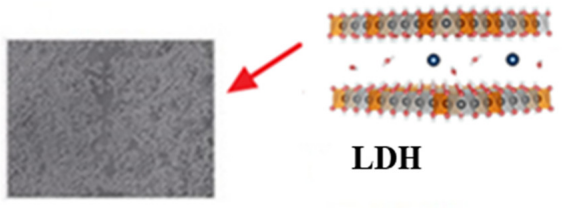

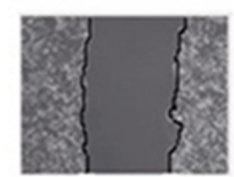

control $\mathbf{t}=\mathbf{0}$
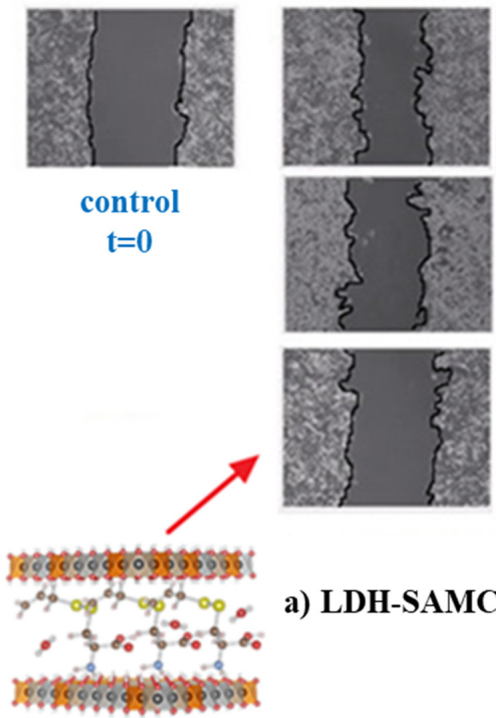

a) LDH-SAMC
$0.1 \%$

$0.5 \%$

$1.0 \%$

$\mathrm{t}=48$ hours

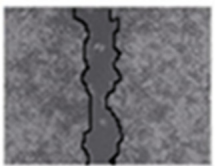

$5 \mu \mathrm{M}$

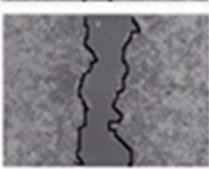

$25 \mu \mathrm{M}$

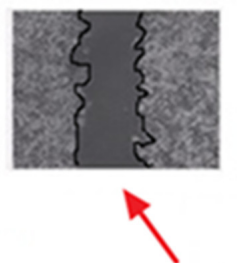

b) SAMC

Figure 10. Results from the scratch test. The migration of HepG2 cells was significantly reduced by treating the cells for $48 \mathrm{~h}$ with the LDH-SAMC preparation (a) in proportion to the increasing concentration from 0.1 to $1.0 \%$ in the culture medium. Treatment with the SAMC molecule alone (b), symbolized by garlic, showed a similar effect, reducing the cell migration in proportion to the concentration set from 5 to $50 \mu \mathrm{M}$, but less than that observed in the presence of the LDH-SAMC component. 
a)

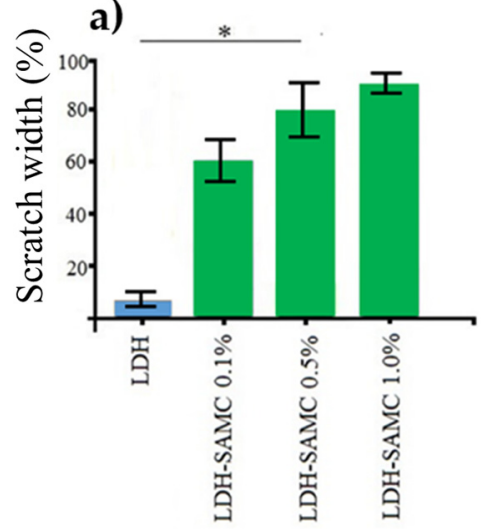

b)

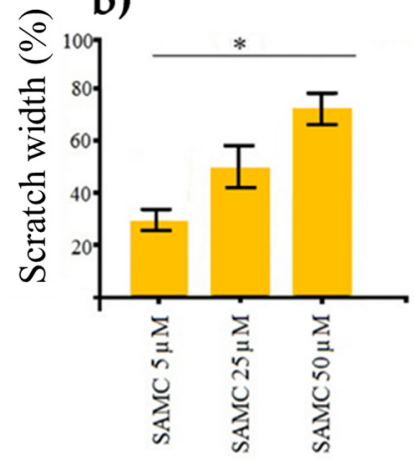

Figure 11. Migration capacity of HepG2 cells after $48 \mathrm{~h}$ of treatment with LDH-SAMC suspension at different concentrations (a) compared with the migration obtained with SAMC alone at salient concentrations in the culture medium (b). ${ }^{*} p<0.05$ as compared with the control set to $100 \%$.

\section{Conclusions}

In this work, the synthesis and characterization of a new intercalation compound LDHSAMC for drug delivery of garlic derivative S-allyl-mercapto-cysteine (SAMC), which is well-known for its anti-tumor properties, is reported. The LDH-SAMC intercalation compound, with the following formula $\left[\mathrm{Zn}_{0.67} \mathrm{Al}_{0.33}(\mathrm{OH})_{2}\right] \mathrm{SAMC}_{0.15}\left(\mathrm{NO}_{3}\right)_{0.18} \cdot 0.6 \mathrm{H}_{2} \mathrm{O}$, was characterized using different techniques, including X-ray powder diffraction, SEM and FT-IR. The resulting data suggested the effective intercalation of the molecule in the layered structure, as confirmed by the (003) reflection in the XRD spectrum for LDH-SAMC, which was shifted to lower $2 \theta$ values (corresponding to an interlay distance of $13.9 \AA$ ). Finally, its release properties in a phosphate buffer medium were determined. A loss of crystallinity upon intercalation, probably due to stacking disorder, was observed and confirmed using a general broadening of the peaks. LDH-SAMC exhibited roughly the same morphological features of pristine LDH precursors in the SEM image. However, more irregular sizes and shapes of the flake-like crystals could be clearly observed, as well as an overall finer structure, with a reduction in the average crystallite size to about $2 \mu \mathrm{m}$. The FT-IR spectrum of LDH-SAMC exhibited a richly structured spectrum in the fingerprint region below $1300 \mathrm{~cm}^{-1}$, whose peaks corresponded to those of functional groups in the SAMC molecule. In vitro drug release studies were performed in a phosphate buffer solution at $\mathrm{pH} 7.2$ and $37^{\circ} \mathrm{C}$ and analyzed using UV spectrophotometry. The SAMC release from the compound was initially characterized by a quick release until $32 \%$ in the first four hours, followed by a slow increase until $42 \%$ after $48 \mathrm{~h}$, and the percentage stabilized and remained constant for the entire period of investigation at around $43 \%$. The solid recovered from the release experiments was characterized using XRD. Since the total release was lower than $40 \%$, the first peak at $14.7 \AA$ very likely belonged to the intercalated form of the LDH with SAMC. The LDH-SAMC complex that was developed in this study offers a very promising approach for the delivery of SAMC to cancer cells.

In conclusion, the preliminary results of the present study highlighted the possibility of improving the response of an anticancer drug [82] via its delivery through LDH particles. This approach was found to be safe and efficient in reducing some of the typical invasive features of a very aggressive tumor, such as human hepatoma. Obviously, the observations made in vitro need subsequent in vivo experimentation, with all its possible limitations. To this end, several in vitro and in vivo studies on this promising therapeutic approach are ongoing in our laboratory.

Author Contributions: Conceptualization, I.V.F., S.B. and P.G.M.; Data curation, G.P., A.M., M.L.D.V., A.P., R.P. and I.B.; Investigation, R.N., G.P., A.M., L.D.G., A.P., M.B. and I.B.; Methodology, R.N., F.C., L.D.G., M.N., M.L.D.V. and S.B.; Resources, P.G.M.; Supervision, F.C., M.N. and P.G.M.; 
Writing—original draft, I.V.F., G.P. and S.B.; Writing—review and editing, R.N., M.B., R.P. and P.G.M. All authors have read and agreed to the published version of the manuscript.

Funding: This research received no external funding.

Institutional Review Board Statement: Not applicable.

Informed Consent Statement: Not applicable.

Data Availability Statement: The study did not report any data.

Acknowledgments: We thank the Wakunaga Pharmaceutical Company, Ltd., 13-4 Arakicho, Shinjyuku-ku, Tokyo 160-0007, Japan, for kindly providing the SAMC.

Conflicts of Interest: The authors declare no conflict of interest.

\section{References}

1. Prescott, L.F. The need for improved drug delivery in clinical practice. In Novel Drug Delivery and Its Therapeutic Application; Prescott, L.F., Nimmo, W.S., Eds.; John Wiley and Sons: West Susset, UK, 1989; pp. 1-11. ISBN 0-471-92154-8.

2. Patra, J.K.; Das, G.; Fraceto, L.F.; Campos, E.V.R.; del Pilar Rodriguez-Torres, M.; Acosta-Torres, L.S.; Diaz-Torres, L.A.; Grillo, R.; Swamy, M.K.; Sharma, S.; et al. Nano Based Drug Delivery Systems: Recent Developments and Future Prospects. J. Nanobiotechnol. 2018, 16, 71. [CrossRef] [PubMed]

3. Wu, J.; Liu, L.; Cai, Y.; Yao, J. Recent Advances of Calcium Phosphate Nanoparticles for Controlled Drug Delivery. MRMC 2013, 13, 1501-1507. [CrossRef]

4. Kalimuthu, K.; Lubin, B.-C.; Bazylevich, A.; Gellerman, G.; Shpilberg, O.; Luboshits, G.; Firer, M.A. Gold Nanoparticles Stabilize Peptide-Drug-Conjugates for Sustained Targeted Drug Delivery to Cancer Cells. J. Nanobiotechnol. 2018, 16, 34. [CrossRef] [PubMed]

5. Kumar, A.; Zhang, X.; Liang, X.-J. Gold Nanoparticles: Emerging Paradigm for Targeted Drug Delivery System. Biotechnol. Adv. 2013, 31, 593-606. [CrossRef]

6. Liu, Z.; Robinson, J.T.; Tabakman, S.M.; Yang, K.; Dai, H. Carbon Materials for Drug Delivery \& Cancer Therapy. Mater. Today 2011, 14, 316-323. [CrossRef]

7. Iturrioz-Rodríguez, N.; Correa-Duarte, M.A.; Fanarraga, M.L. Controlled Drug Delivery Systems for Cancer Based on Mesoporous Silica Nanoparticles. Int. J. Nanomed. 2019, 14, 3389-3401. [CrossRef]

8. Vangijzegem, T.; Stanicki, D.; Laurent, S. Magnetic Iron Oxide Nanoparticles for Drug Delivery: Applications and Characteristics. Expert Opin. Drug Deliv. 2019, 16, 69-78. [CrossRef]

9. Riaz, U.; Ashraf, S.M. Double Layered Hydroxides as Potential Anti-Cancer Drug Delivery Agents. Mini Rev. Med. Chem. 2013, 13, 522-529. [CrossRef]

10. Yan, L.; Gonca, S.; Zhu, G.; Zhang, W.; Chen, X. Layered Double Hydroxide Nanostructures and Nanocomposites for Biomedical Applications. J. Mater. Chem. B. 2019, 7, 5583-5601. [CrossRef]

11. Ameena Shirin, V.K.; Sankar, R.; Johnson, A.P.; Gangadharappa, H.V.; Pramod, K. Advanced Drug Delivery Applications of Layered Double Hydroxide. J. Control. Release 2021, 330, 398-426. [CrossRef]

12. Wen, J.; Yang, K.; Huang, J.; Sun, S. Recent Advances in LDH-Based Nanosystems for Cancer Therapy. Mater. Des. 2021, 198, 109298. [CrossRef]

13. Ladewig, K.; Xu, Z.P.; Lu, G.Q. (Max) Layered Double Hydroxide Nanoparticles in Gene and Drug Delivery. Expert Opin. Drug Deliv. 2009, 6, 907-922. [CrossRef]

14. Jin, W.; Ha, S.; Myung, J.-H.; Kim, B.C.; Park, D.-H. Ceramic Layered Double Hydroxide Nanohybrids for Therapeutic Applications. J. Korean Ceram. Soc. 2020, 57, 597-607. [CrossRef]

15. Ahmed, A.A.A.; Talib, Z.A.; bin Hussein, M.Z.; Zakaria, A. Zn-Al Layered Double Hydroxide Prepared at Different Molar Ratios: Preparation, Characterization, Optical and Dielectric Properties. J. Solid State Chem. 2012, 191, 271-278. [CrossRef]

16. Guo, X.; Zhang, F.; Evans, D.G.; Duan, X. Layered Double Hydroxide Films: Synthesis, Properties and Applications. Chem. Commun. 2010, 46, 5197. [CrossRef] [PubMed]

17. Feitknecht, W.; Gerber, M. Zur Kenntnis Der Doppelhydroxyde Und Basischen Doppelsalze III. Über MagnesiumAluminiumdoppelhydroxyd. Helv. Chim. Acta 1942, 25, 131-137. [CrossRef]

18. Di Vona, M.L.; Casciola, M.; Donnadio, A.; Nocchetti, M.; Pasquini, L.; Narducci, R.; Knauth, P. Anionic Conducting Composite Membranes Based on Aromatic Polymer and Layered Double Hydroxides. Int. J. Hydrogen Energy 2017, 42, 3197-3205. [CrossRef]

19. De Roy, A.; Forano, C.; Besse, J.P. Layered double hydroxides: Synthesis and post-synthesis modification. In Layered Double Hydroxides: Present and Future; Rives, V., Ed.; Nova Science Publishers, Inc.: New York, NY, USA, 2001; pp. 1-39. ISBN 978-1-63482-212-1.

20. Cavani, F.; Trifirò, F.; Vaccari, A. Hydrotalcite-Type Anionic Clays: Preparation, Properties and Applications. Catal. Today 1991, 11, 173-301. [CrossRef]

21. Arrabito, G.; Bonasera, A.; Prestopino, G.; Orsini, A.; Mattoccia, A.; Martinelli, E.; Pignataro, B.; Medaglia, P.G. Layered Double Hydroxides: A Toolbox for Chemistry and Biology. Crystals 2019, 9, 361. [CrossRef]

22. Laipan, M. Functionalized Layered Double Hydroxides for Innovative Applications. Mater. Horiz. 2019, 31, 715-745. [CrossRef] 
23. Richetta, M.; Digiamberardino, L.; Mattoccia, A.; Medaglia, P.G.; Montanari, R.; Pizzoferrato, R.; Scarpellini, D.; Varone, A.; Kaciulis, S.; Mezzi, A.; et al. Surface Spectroscopy and Structural Analysis of Nanostructured Multifunctional (Zn, Al) Layered Double Hydroxides: XPS and UPS Investigation of Nanostructured Multifunctional LDH. Surf. Interface Anal. 2016, 48, 514-518. [CrossRef]

24. Pizzoferrato, R.; Ciotta, E.; Ferrari, I.V.; Braglia, M.; Medaglia, P.G.; Mattoccia, A.; Di Giamberardino, L.; Richetta, M.; Knauth, P.; Di Vona, M.L. Ionic Conductivity of Zn Al Layered Double Hydroxide Films Grown on Aluminum Substrate. Solid State Ion. 2018, 314, 30-35. [CrossRef]

25. Costantino, U.; Ambrogi, V.; Nocchetti, M.; Perioli, L. Hydrotalcite-like Compounds: Versatile Layered Hosts of Molecular Anions with Biological Activity. Microporous Mesoporous Mater. 2008, 107, 149-160. [CrossRef]

26. Costantino, U.; Nocchetti, M.; Sisani, M.; Vivani, R. Recent Progress in the Synthesis and Application of Organically Modified Hydrotalcites. Z. Für Krist. 2009, 224, 273-281. [CrossRef]

27. Prestopino, G.; Arrabito, G.; Generosi, A.; Mattoccia, A.; Paci, B.; Perez, G.; Verona-Rinati, G.; Medaglia, P.G. Emerging Switchable Ultraviolet Photoluminescence in Dehydrated Zn/Al Layered Double Hydroxide Nanoplatelets. Sci. Rep. 2019, 9 , 11498. [CrossRef]

28. Pagano, C. Folic Acid-Layered Double Hydroxides Hybrids in Skin Formulations-Technological, Photochemical and in Vitro Cytotoxicity on Human Keratinocytes and Fibroblasts. Appl. Clay Sci. 2019, 14, 382-389. [CrossRef]

29. Sels, B.F.; De Vos, D.E.; Jacobs, P.A. Hydrotalcite-like Anionic Clays in Catalytic Organic Reactions. Catal. Rev. 2001, 43, 443-488. [CrossRef]

30. Di Fronzo, A.; Pirola, C.; Comazzi, A.; Galli, F.; Bianchi, C.L.; Di Michele, A.; Vivani, R.; Nocchetti, M.; Bastianini, M.; Boffito, D.C. Co-Based Hydrotalcites as New Catalysts for the Fischer-Tropsch Synthesis Process. Fuel 2014, 119, 62-69. [CrossRef]

31. Wang, Y.; Yan, D.; El Hankari, S.; Zou, Y.; Wang, S. Recent Progress on Layered Double Hydroxides and Their Derivatives for Electrocatalytic Water Splitting. Adv. Sci. 2018, 5, 1800064. [CrossRef]

32. Wang, K.; Wang, T.; Islam, Q.A.; Wu, Y. Layered Double Hydroxide Photocatalysts for Solar Fuel Production. Chin. J. Catal. 2021, 42, 1944-1975. [CrossRef]

33. Chen, H.; Zhang, F.; Fu, S.; Duan, X. In Situ Microstructure Control of Oriented Layered Double Hydroxide Monolayer Films with Curved Hexagonal Crystals as Superhydrophobic Materials. Adv. Mater. 2006, 18, 3089-3093. [CrossRef]

34. Cao, K.; Yu, Z.; Zhu, L.; Yin, D.; Chen, L.; Jiang, Y.; Wang, J. Fabrication of Superhydrophobic Layered Double Hydroxide Composites to Enhance the Corrosion-Resistant Performances of Epoxy Coatings on Mg Alloy. Surf. Coat. Technol. 2021, 407, 126763. [CrossRef]

35. Zubair, M.; Daud, M.; McKay, G.; Shehzad, F.; Al-Harthi, M.A. Recent Progress in Layered Double Hydroxides (LDH)-Containing Hybrids as Adsorbents for Water Remediation. Appl. Clay Sci. 2017, 143, 279-292. [CrossRef]

36. Chaillot, D.; Bennici, S.; Brendlé, J. Layered Double Hydroxides and LDH-Derived Materials in Chosen Environmental Applications: A Review. Environ. Sci. Pollut. Res. 2021, 28, 24375-24405. [CrossRef]

37. Tang, Z.; Qiu, Z.; Lu, S.; Shi, X. Functionalized Layered Double Hydroxide Applied to Heavy Metal Ions Absorption: A Review. Nanotechnol. Rev. 2020, 9, 800-819. [CrossRef]

38. Pizzoferrato, R.; Ciotta, E.; Ferrari, I.V.; Narducci, R.; Pasquini, L.; Varone, A.; Richetta, M.; Antonaroli, S.; Braglia, M.; Knauth, P.; et al. Layered Double Hydroxides Containing an Ionic Liquid: Ionic Conductivity and Use in Composite Anion Exchange Membranes. ChemElectroChem 2018, 5, 2781-2788. [CrossRef]

39. Sajid, M.; Sajid Jillani, S.M.; Baig, N.; Alhooshani, K. Layered Double Hydroxide-Modified Membranes for Water Treatment: Recent Advances and Prospects. Chemosphere 2021, 287, 132140. [CrossRef]

40. Zhou, Y. Applications of Two-Dimensional Layered Nanomaterials in Photoelectrochemical Sensors: A Comprehensive Review. Coord. Chem. Rev. 2021, 48, 214156. [CrossRef]

41. Sohrabi, H.; Khataee, A.; Ghasemzadeh, S.; Majidi, M.R.; Orooji, Y. Layer Double Hydroxides (LDHs)-Based Electrochemical and Optical Sensing Assessments for Quantification and Identification of Heavy Metals in Water and Environment Samples: A Review of Status and Prospects. Trends Environ. Anal. Chem. 2021, 31, e00139. [CrossRef]

42. Tomassetti, M.; Pezzilli, R.; Prestopino, G.; Natale, C.D.; Medaglia, P.G. Fabrication and Characterization of a Layered Double Hydroxide Based Catalase Biosensor and a Catalytic Sensor for Hydrogen Peroxide Determination. Microchem. J. 2021, 106700. [CrossRef]

43. Polese, D.; Mattoccia, A.; Giorgi, F.; Pazzini, L.; Di Giamberardino, L.; Fortunato, G.; Medaglia, P.G. A Phenomenological Investigation on Chlorine Intercalated Layered Double Hydroxides Used as Room Temperature Gas Sensors. J. Alloys Compd. 2017, 692, 915-922. [CrossRef]

44. Munyemana, J.C.; Chen, J.; Han, Y.; Zhang, S.; Qiu, H. A Review on Optical Sensors Based on Layered Double Hydroxides Nanoplatforms. Microchim. Acta 2021, 188, 80. [CrossRef]

45. Tadanaga, K.; Furukawa, Y.; Hayashi, A.; Tatsumisago, M. Direct Ethanol Fuel Cell Using Hydrotalcite Clay as a Hydroxide Ion Conductive Electrolyte. Adv. Mater. 2010, 22, 4401-4404. [CrossRef] [PubMed]

46. Gao, X.; Wang, P.; Pan, Z.; Claverie, J.P.; Wang, J. Recent Progress in Two-Dimensional Layered Double Hydroxides and Their Derivatives for Supercapacitors. ChemSusChem 2020, 13, 1226-1254. [CrossRef] 
47. Boumeriame, H.; Da Silva, E.S.; Cherevan, A.S.; Chafik, T.; Faria, J.L.; Eder, D. Layered Double Hydroxide (LDH)-Based Materials: A Mini-Review on Strategies to Improve the Performance for Photocatalytic Water Splitting. J. Energy Chem. 2021, 64, 406-431. [CrossRef]

48. Zhang, Y.; Xu, H.; Lu, S. Preparation and Application of Layered Double Hydroxide Nanosheets. RSC Adv. 2021, 11, $24254-24281$. [CrossRef]

49. Taviot-Guého, C.; Prévot, V.; Forano, C.; Renaudin, G.; Mousty, C.; Leroux, F. Tailoring Hybrid Layered Double Hydroxides for the Development of Innovative Applications. Adv. Funct. Mater. 2018, 28, 1703868. [CrossRef]

50. Rives, V.; del Arco, M.; Martín, C. Intercalation of Drugs in Layered Double Hydroxides and Their Controlled Release: A Review. Appl. Clay Sci. 2014, 88-89, 239-269. [CrossRef]

51. Costantino, U.; Nocchetti, M. Layered double hydroxides and their intercalation compounds in photochemistry and in medicinal chemistry. In Layered Double Hydroxides: Present and Future; Rives, V., Ed.; Nova Science Publishers, Inc.: New York, NY, USA, 2001; pp. 435-468. ISBN 978-1-63482-212-1.

52. Chatterjee, A.; Bharadiya, P.; Hansora, D. Layered Double Hydroxide Based Bionanocomposites. Appl. Clay Sci. 2019, 177, 19-36. [CrossRef]

53. Wei, M.; Guo, J.; Shi, Z.; Yuan, Q.; Pu, M.; Rao, G.; Duan, X. Preparation and Characterization of L-Cystine and 1-Cysteine Intercalated Layered Double Hydroxides. J. Mater. Sci. 2007, 42, 2684-2689. [CrossRef]

54. Dasgupta, P.; Bhattacharya, A.; Pal, R.; Dasgupta, A.K.; Sengupta (Bandyopadhayay), S. Synthesis of Diallyl Disulfide (DADS) Induced Gold Nanoparticles: Characterization and Study of Its Biological Activity in Human Leukemic Cell-Lines. RSC Adv. 2015, 5, 18429-18437. [CrossRef]

55. Ramachandran, E.; Natarajan, S. Crystal Growth of Some Urinary Stone Constituents: III. In-Vitro Crystallization of L-Cystine and Its Characterization. Cryst. Res. Technol. 2004, 39, 308-312. [CrossRef]

56. Nikolić, V.D.; Ilić, D.P.; Nikolić, L.B.; Stanković, M.Z.; Stanojević, L.P.; Savić, I.M.; Savić, I.M. The synthesis and structure characterization of deoxyalliin and alliin. Adv. Technol. 2012, 9, 38-46.

57. Liang, D. S-Allylmercaptocysteine Effectively Inhibits the Proliferation of Colorectal Cancer Cells under in Vitro and in Vivo Conditions. Cancer Lett. 2011, 8, 69-76. [CrossRef] [PubMed]

58. Zhang, Y.; Li, H.-Y.; Zhang, Z.-H.; Bian, H.-L.; Lin, G. Garlic-Derived Compound S-Allylmercaptocysteine Inhibits Cell Growth and Induces Apoptosis via the JNK and P38 Pathways in Human Colorectal Carcinoma Cells. Oncol. Lett. 2014, 8, $2591-2596$. [CrossRef] [PubMed]

59. Xiao, D.; Pinto, J.T.; Soh, J.-W.; Deguchi, A.; Gundersen, G.G.; Palazzo, A.F.; Yoon, J.-T.; Shirin, H.; Weinstein, I.B. Induction of Apoptosis by the Garlic-Derived Compound S-Allylmercaptocysteine (SAMC) Is Associated with Microtubule Depolymerization and c-Jun NH2-Terminal Kinase 1 Activation. Cancer Res. 2003, 63, 6825-6837. [PubMed]

60. Shirin, H.; Pinto, J.T.; Kawabata, Y.; Soh, J.-W.; Delohery, T.; Moss, S.F.; Murty, V.; Rivlin, R.S.; Holt, P.R.; Weinstein, I.B. Antiproliferative Effects of S-Allylmercaptocysteine on Colon Cancer Cells When Tested Alone or in Combination with Sulindac Sulfide. Cancer Res. 2001, 61, 725-731.

61. Sigounas, G.; Hooker, J.; Anagnostou, A.; Steiner, M. S-allylmercaptocysteine Inhibits Cell Proliferation and Reduces the Viability of Erythroleukemia, Breast, and Prostate Cancer Cell Lines. Nutr. Cancer 1997, 27, 186-191. [CrossRef] [PubMed]

62. Kaschula, C.H.; Hunter, R.; Cotton, J.; Tuveri, R.; Ngarande, E.; Dzobo, K.; Katz, A.A.; Parker, M.I. The Garlic Compound Ajoene Targets Protein Folding in the Endoplasmic Reticulum of Cancer Cells. Mol. Carcinog. 2016, 55, 1213-1228. [CrossRef]

63. Bastianini, M.; Costenaro, D.; Bisio, C.; Marchese, L.; Costantino, U.; Vivani, R.; Nocchetti, M. On the Intercalation of the Iodine-Iodide Couple on Layered Double Hydroxides with Different Particle Sizes. Inorg. Chem. 2012, 51, 2560-2568. [CrossRef]

64. Strober, W. Trypan Blue Exclusion Test of Cell Viability. Curr. Protoc. Immunol. 2015, 111. [CrossRef] [PubMed]

65. Pantanowitz, L.; Miller, K.B.; Ford, J.C.; Beckwith, B.A. The scratch test. Arch. Pathol. Lab. Med. 2004, 128, 598. [CrossRef]

66. Chai, H.; Xu, X.; Lin, Y.; Evans, D.G.; Li, D. Synthesis and UV Absorption Properties of 2,3-Dihydroxynaphthalene-6-Sulfonate Anion-Intercalated Zn-Al Layered Double Hydroxides. Polym. Degrad. Stab. 2009, 94, 744-749. [CrossRef]

67. Wei, M.; Pu, M.; Guo, J.; Han, J.; Li, F.; He, J.; Evans, D.G.; Duan, X. Intercalation of L-Dopa into Layered Double Hydroxides: Enhancement of Both Chemical and Stereochemical Stabilities of a Drug through Host-Guest Interactions. Chem. Mater. 2008, 20, 5169-5180. [CrossRef]

68. Parida, K.M. Synthesis and Characterization of a Fe(III)-Schiff Base Complex in a Zn-Al LDH Host for Cyclohexane Oxidation. Chemical 2010, 6, 7-12. [CrossRef]

69. Feng, Y.; Li, D.; Wang, Y.; Evans, D.G.; Duan, X. Synthesis and Characterization of a UV Absorbent-Intercalated Zn-Al Layered Double Hydroxide. Polym. Degrad. Stab. 2006, 91, 789-794. [CrossRef]

70. Arizaga, G.G.C.; da Costa Gardolinski, J.E.F.; Schreiner, W.H.; Wypych, F. Intercalation of an Oxalatooxoniobate Complex into Layered Double Hydroxide and Layered Zinc Hydroxide Nitrate. J. Colloid Interface Sci. 2009, 330, 352-358. [CrossRef]

71. Benício, L.P.F.; Eulálio, D.; Guimarães, L.D.M.; Pinto, F.G.; Costa, L.M.D.; Tronto, J. Layered Double Hydroxides as Hosting Matrices for Storage and Slow Release of Phosphate Analyzed by Stirred-Flow Method. Mater. Res. 2018, 21. [CrossRef]

72. Clause, O.; Gazzano, M.; Trifiro, F.; Vaccari, A.; Zatorski, L. Preparation and Thermal Reactivity of Nickel/Chromium and Nickel/Aluminium Hydrotalcite-Type Precursors. Appl. Catal. 1991, 73, 217-236. [CrossRef]

73. Rastogi, L. Green Synthetic Route For The Size Controlled Synthesis Of Biocompatible Gold Nanoparticles Using Aqueous Extract Of Garlic (Allium Sativum). Adv. Mater. Lett. 2013, 4, 548-555. [CrossRef] 
74. Socrates, G. Infrared and Raman Characteristic Group Frequencies: Tables and Charts, 3rd ed.; Wiley, C.J., Ed.; Wiley: New York, NY, USA, 2004; ISBN 978-0-470-09307-8.

75. Ramaswamy, S.; Rajaram, R.K.; Ramakrishnan, V. Infrared and Laser Raman Spectra of Bis(DL-Methioninium) Sulfate. J. Raman Spectrosc. 2005, 36, 840-847. [CrossRef]

76. Rezvani, Z.; Arjomandi Rad, F.; Khodam, F. Synthesis and Characterization of Mg-Al-Layered Double Hydroxides Intercalated with Cubane-1,4-Dicarboxylate Anions. Dalton Trans. 2015, 44, 988-996. [CrossRef]

77. Nakayama, H.; Wada, N.; Tsuhako, M. Intercalation of Amino Acids and Peptides into Mg-Al Layered Double Hydroxide by Reconstruction Method. Int. J. Pharm. 2004, 269, 469-478. [CrossRef]

78. Minagawa, K.; Berber, M.R.; Hafez, I.H.; Mori, T.; Tanaka, M. Target Delivery and Controlled Release of the Chemopreventive Drug Sulindac by Using an Advanced Layered Double Hydroxide Nanomatrix Formulation System. J. Mater. Sci. Mater. Med. 2012, 23, 973-981. [CrossRef]

79. Khan, S.B.; Alamry, K.A.; Alyahyawi, N.A.; Asiri, A.M.; Arshad, M.N.; Marwani, H.M. Nanohybrid Based on Antibiotic Encapsulated Layered Double Hydroxide as a Drug Delivery System. Appl. Biochem. Biotechnol. 2015, 175, 1412-1428. [CrossRef]

80. Liu, J.; Song, J.; Xiao, H.; Zhang, L.; Qin, Y.; Liu, D.; Hou, W.; Du, N. Synthesis and Thermal Properties of ZnAl Layered Double Hydroxide by Urea Hydrolysis. Powder Technol. 2014, 253, 41-45. [CrossRef]

81. Inayat, A.; Klumpp, M.; Schwieger, W. The Urea Method for the Direct Synthesis of ZnAl Layered Double Hydroxides with Nitrate as the Interlayer Anion. Appl. Clay Sci. 2011, 51, 452-459. [CrossRef]

82. Xiao, J.; Xing, F.; Liu, Y.; Lv, Y.; Wang, X.; Ling, M.-T.; Gao, H.; Ouyang, S.; Yang, M.; Zhu, J.; et al. Garlic-Derived Compound SAllylmercaptocysteine Inhibits Hepatocarcinogenesis through Targeting LRP6/Wnt Pathway. Acta Pharm. Sin. B 2018, 8, 575-586. [CrossRef] 